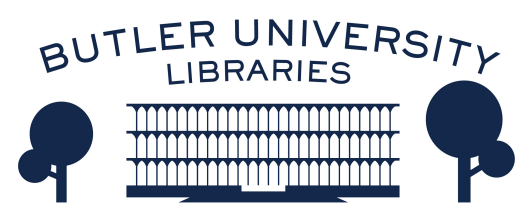

Journal of Hindu-Christian Studies

Volume 3

Article 3

January 1990

\title{
The Transformation of the Scholar as a Factor in Hindu-Christian Studies
}

Francis X. Clooney

Follow this and additional works at: https://digitalcommons.butler.edu/jhcs

Part of the Religion Commons

\section{Recommended Citation}

Clooney, Francis X. (1990) "The Transformation of the Scholar as a Factor in Hindu-Christian Studies," Journal of Hindu-Christian Studies: Vol. 3, Article 3.

Available at: https://doi.org/10.7825/2164-6279.1026

The Journal of Hindu-Christian Studies is a publication of the Society for Hindu-Christian Studies. The digital version is made available by Digital Commons @ Butler University. For questions about the Journal or the Society, please contact cbauman@butler.edu. For more information about Digital Commons @ Butler University, please contact digitalscholarship@butler.edu. 


\title{
The Transformation of the Scholar as a Factor in Hindu-Christian Studies Francis X. Clooney, S. J. University of Chicago
}

\begin{abstract}
A lively, varied range of scholarly activities is gathered today under the title of "Hindu-Christian studies." Indeed, we find as many different approaches and interests surfacing in this field as can be found in other areas of theology and the study of religion. The wealth of material that deals with the study of the religions grouped loosely under the titles of "Hinduism" and "Christianity" is itself enormous and still growing. Now, in addition, many of us are documenting and predicting the relationships among these religions; monographs, collections of essays and, most recently, this journal, all offer us considerations of how the religions have interacted, how they are similar and differ, what the implications of the growing mutual information and respect are, etc.

These studies and "meta-studies" indicate the gradual maturation of the field. But the concomitant growth in complexity means that none of us can really master the whole anymore; we are all specialists, we focus most of our attention on particular areas of interest, and we work with materials in certain language areas, according to certain methods we have learned. Part of our present task, I suggest, is to chart more carefully what is happening to us as specialists, and how we are developing differently depending on the kind of research we are doing; we need to say more about how our particular areas of expertise differ, how our different ways of researching, teaching and writing arise from different kinds of encounters with the religion and culture that is new to us, and how, consequently, the nature and aim of "Hindu-Christian studies" is to be articulated in different ways by each of us, even if ostensibly we are writing on the same themes.

This essay seeks to exemplify certain aspects and benefits of "this turn to the scholar," by reflecting on some of the effects that my own study of Hinduism that on me as an Indologist and theologian.

As a Christian who has been studying classical, systematic texts of Hinduism and writing increasingly with a Christian theological audience in mind, I have had to find my own way through the broad possibilities of study related to Hinduism, I have had to select my own focus, raise just some and not all questions regarding the material, and finally identify my specific audiences and the proper means of communication with them.

As it has turned out, and despite a number of other approaches to India and religion I could have taken up, I have turned out to be a reader of texts, one who specializes in primary texts and the discovery of their meanings. I read, instead of learning about religion by other available, fruitful and interesting means, such as observing ritual performances, or interviewing informants about family and caste customs, or even engaging in Hindu-Christian dialogues. Although thus far I have spent about three years on the subcontinent (in Kathmandu and later in Madras), most of what I know has come from reading.
\end{abstract}

Hindu-Christian Studies Bulletin 3 (1990) 1-6 
That I am a reader informs how I approach the wider range of issues related to Hindu-Christian studies. Learning from texts has its own procedures and implications, and these in turn have an important effect on what is thereafter written and communicated to a wider scholarly and religious audience. For, like any other reader, the reader of a religious text is transformed by that reading. As the readerengages in a prolonged engagement with a classic text, she or he has to keep responding to its demands, its ways of saying or not saying quite what it means, of presupposing what some readers know and others don't. But the reader also constructs the text: she or he has to construct a "reader's version" of it, by the incremental process of deciphering its meaning, part and whole, deciding what is most important, then re-reading it accordingly, modifying earlier interpretations, etc. One thereby constructs for it a meaning that was never simply there, "on the page." This attainment of a broader literacy and skill in reading is a real form of interreligious relationship, but one that differs from engaging in dialogues, or participating in a community's daily life, etc.

Second, not all textual studies are alike; different texts affect their readers in different ways. Thus, even if everyone in a given group of Christian theologians, for example, might rightly be called a "scholar of Hindu texts," the research, the mode of writing and presentation of each are likely to have different characters, depending on the texts each studies: thus, one scholar reflects on a somewhat obscure but much commented on text of sruti; a second maps the mythological world of the puranas, a third thinks through the classical systematizations of the darsanas, and a fourth enjoys modern vernacular bhajans. Though all read Hindu texts, they differ as scholars and writers according to what they have been reading. Add to this the wide variety of Christian texts Hindus are reading and we have a complex set of subfactors to take into account when assessing what any of us, Hindu or Christian, say about the Hindu-Christian relationship.

Let us focus now on my own reading as an example. Over the past ten years, my study has focused on a triple strand of classical and brahmanical texts which, though in its part too complex and independent-minded to be labeled a single tradition, bear a series of continuities and cumulative "family resemblances" that persist despite substantial differences: first, the Purva Mimāms $\bar{a}$, a system of textualritual analysis which reconstructs the Vedic world of speech and practice; second, the later, Uttara Mimāms $\bar{a}$ which extends and enlarges the Mimamsa discourse to include the upanisads as the privileged center of that Vedic world; third, the Srivaisnava tradition of southern India, which further enlarges the received Sanskrit tradition by its acceptance of the Tamil works of the Alvars as primary, honored religious texts at least on par with the Vedas, and then by learning to write differently, in a discourse that borrows from both Sanskrit and Tamil.

Each of these three interconnected areas of study is vast and complex; together they are the material for several lifetimes of work. I have only begun to find my way around in some of the pertinent texts of each, and so am far from any magisterial statements about their meaning. But I have already discovered that the study of these materials has influenced my scholarly work in interesting and not 
entirely predictable ways - not just regarding this or that theme or question which I pose, but also regarding how I read and how I write.

In what follows, I wish to indicate in a preliminary fashion how my reading of Mimamsa, Vedanta and Srivaisnava texts has changed my work as a scholar and theologian, in particular ways, I will sketch, in very broad terms, three pairs of terms that I have learned about, and which have helped shape my understanding of the communicative value of texts: Mimamsa's distinction between vidhi and arthava $\bar{a} d a$; Vedanta's distinction between saguna and nirguna statements; Srivaisnavism's distinction between svāpadena and anyāpadena.

Mimamsa hierarchizes the parts of sacred texts by distinguishing those with an injunctive function, which tell us what to do, from those with a descriptive/supportive function, which support, explain and encourage the enjoined action. In all Vedic texts the obligatory power of the text (the vidhi or, more fundamentally, the codana $\bar{a}$ ), which instigates the "reader" to perform certain ritual actions in a certain way, is primary, and supported by a largely informative and exhortatory discourse (arthavāda), which locates it in the "reader's" world and by various persuasive means shows why the vidhi should be obeyed. All scripture passages are either vidhi or arthav $\bar{a} d a$, and all are thus directly or supportively intent on action. Texts are never simply narrations of sources of information to be received and assimilated; they are projects that seek to engage their readers, and which therefore need to be assessed according to what they demand from the reader.

Reading a considerable amount of Mimamsa has made me gradually accustomed to assume that texts (Vedic and otherwise) are meant to communicate to their readers a demand for action, a meaning that is a purpose; texts are properly understood when I know what their "authors" want from me. Underlying proffered information is always an appeal to behave in a certain way, an appeal supported by that information. Accordingly, I have discerned a shift in my expectations in reading, toward the "performative side." I tend to look for a text's agenda, what the writer, knowingly or not, is asking me to do, and I must make a conscious effort simply to read a text, religious or otherwise, for the sake of its information.

So too, when I write, I find myself assuming that my text will be a better one if it asks something definite of its readers, and if the information I give is properly martialled in support of what I am asking. Nothing superfluous, merely interesting or novel, has a place. Although I can notionally admit that academic writing has other, simply informative functions, and that there is (or should be) room for pure research in Hindu-Christian scholarship, my engagement in Mimamsa has led me to presuppose that research on religion and religions is always in support of an agenda, preferably a religious one. (If this is an old point of view, I have nevertheless come to it by a novel path, Mimamsa.)

Vedanta differs from Mimamsa in insisting that texts give us important information that is salvific in itself, and not merely supportive of commands to action. But the Vedantins were not entirely immune to Mimamsa's performative reading of texts; for they read the upanișads with an eye to their central salvific and transformative effects, and they subordinate all else, including "descriptions" of 


\section{Transformation of the Scholar}

brahman, to the goal of the transformation of the reader through realization of brahman.

An important instance of Advaita's definition of a performative reception of texts is its well-known distinction between texts that refer to brahman without qualifications (nirguna) and those that refer to brahman as qualified by various attributes (saguna). Saguna texts help the meditating Vedantin to focus attention during a particular act of meditation, by localizing brahman with a certain form and shape. Nirguna texts, though also used in specific acts of meditation, communicate by gradually excluding wrong understandings of the object of communication, discarding one by one various ostensible specifications of brahman. They do this by a series of intended "mis-speakings" that invite and then defuse "mis-reading." Thus, one may begin by thinking a text informs us that brahman is "bliss," but eventually the attentive reader needs to realize how the word "bliss" serves to discard any hint of sorrow, and not to characterize brahman directly. The ultimate impact of a text on a reader of Vedanta is the cumulatively effected transition from saguna language to nirguna language: from and through what is said, to the "not-said," a final, nonobjectified knowledge of brahman which, though "beyond words," is available only to the Vedantin who has first learned to understand words properly.

Reading a good amount of Advaita Vedanta-Samkara, of course, but also Ananda Giri, Vacaspati Misra, Amalananda, etc. - has gradually changed my attitude toward what I think I know, and toward the sources of that knowledge and my words about it. If the Mimamsa distinction of vidhi and arthazada returns us again and again to the question of the point of a text, its "what for," the Vedanta distinction of the nirguna from the saguna presses the question of the status of the text, its writing and being read, vis-à-vis the intended object and audience of communication. To read is to be taught by words that religious words can never really communicate what they ultimately mean. Then, to write religiously is to use words strategically, to "inscribe" in the reader elusive "indications" that can never be written explicitly, but which occur only as "after-words." The result is a highly literate inarticulateness, which becomes a precious resource for the writer.

If one attempts to write after reading Advaita Vedanta, it is hard to avoid the feeling that what one is actually writing about Hinduism or Christianity, or religion in general, bears with it the more subtle agenda of designedly not saying, and leaving clearly unspoken, "something else." The more one has to say, the greater the role of this "unsaid." If I may generalize: a thorough immersion in Vedanta promotes the view that the real object of "Hindu-Christian studies" is a profoundly inarticulable referent which eludes the grasp of words - but which is noticed in its absence only after thorough, meticulous cross-religious research has been carried through and interiorized. The Vedantin tells us that the properly religious aspect of HinduChristian studies resides in this consequent achieved silence.

The Srivaisnava commentators who interpreted Nammaivar's Tiruvāymoli the most important of the works of the twelve aivars (6th-9th centuries)-were welltrained in Mimamsa and Vedanta ways of reading, but they added a few rules of their own. For example, in the process of learning to sort out and order the hundred lovely but strikingly diverse songs of Tiruvaymoli, they made a distinction between songs in 
Francix X. Clooney, S. J. 5

which Nammaivar speaks "in his own voice," directly expressing himself, and those in which he speaks "in another voice," saying what could not be said directly: his songs were, as they put it, either svāpadesa or anyāpadesa.

This terminological distinction was intended to explain the noticeably different style and tone between those songs in Tiruvaymoli that speak "correctly" of Visnu as perfect, good, always faithful, etc., and those sung in the voice of a young woman bereft of her [divine] lover, a woman who expresses toward her lord a range of powerful emotions including lust, anger and despair. The former, "proper" songs were in Nammaivar's own voice (sväpadesa), the latter in "another's" voice (anyāpadesa). The distinction explains how Nammaivar taken to be the model of theological correctness and complete faithfulness could be found saying things that would appear inappropriate in the model devotee. As himself, the solution is, he says only what conforms to the community's most proper doctrine; as "her," he speaks what is religiously powerful but unassimilable as a common discourse. Those skilled in the literary device can read both kinds of song properly, without literary or theological confusion.

Upon reflection, and notwithstanding the fact that in this case the suggested parallelism is only partial, I have found that the way I write has been subtly influenced also by this Srivaisnava distinction between what one says in one's own voice and what one must say otherwise. For I have begun to see that as a Christian and scholar I in fact shift from "voice" to "voice" in my writing, using this shift (often unconsciously) in order to say different things to different audiences - or, perhaps, to the same audience under different circumstances.

For, like the Srivaisnavas, I belong to a structured community, the Roman Catholic. I write from within, and for, a community that is possessed not only of a long doctrinal tradition, but also of a central teaching authority; not everything one learns in one's specialization, such as Indology, can be stated directly in a Catholic context. But by wearing the two "hats" of Indologist and theologian, I have been given the possibility of writing in two, only partially intersecting discourses. As an Indologist, I study Hindu texts with a certain objectivity and then sympathy that can be directly communicated in my Indological writings. I can simply say what I have to say.

But the retrieval of Indological material and its exposition are transmuted when I speak as a Christian, to a Christian audience. In this environment, where one begins to reflect on different faiths seeking and articulating different understandings, there is likely to be a collision of sympathies; among "believers," the scholar's presentation of the material about another religion comes under a different kind of scrutiny, and different questions are posed: are "they" right? do you believe what "they" say? how can "they" know the truth if "we" do? One has to negotiate the tension between two sympathies, and it is often the case that one cannot really say what one knows, without seeming to separate oneself from the home community by making strong claims about the goodness and truth of another religion or betraying the "other" by portraying it as deficient in comparison with what the community values. 


\section{Transformation of the Scholar}

Reading Srivaisnava texts has not solved my problem, but it has afforded me a modus operandi according to which I can continue to write: the language of Indological scholarship to some extent serves as my anyāpadesa, wherein I can say things that are not, or at least not yet, assimilable into the Christian theological language which is my svāpadesa. The Srivaisnava theologians have afforded me a precedent for believing that speaking in more than one voice can be a necessary and valid religious strategy, one that does not preclude the later possibility of understanding the several voices as harmonious, even one.

To conclude. My study of Mimamsa, Vedanta and Srivaisnavism has moved ahead primarily through a focus on particular themes and particular texts, to understand them and then present them according to certain modern standards. But I have found, in retrospect, that this research has also changed in subtle and important ways how I work as a scholar, how I go about reading, speaking and writing religiously. This change may ultimately be more significant than any research information I manage to convey. Like a Mimamsaka, I tend now to look for what any given text is "really" asking me to do, and I tend to write with a fairly definite agenda in mind; like an Advaitin, I calculate more carefully how the inherent inadequacy of words and texts can speak to readers through what is written and toward what is beyond the written; like a Srivaisnava, I consider more carefully the possibilities of shifts in discourse and audience, when I decide what to say to whom. Together, all of this serves to give a distinct character to how I go about being a scholar and theologian.

I do not mean that others who study these traditions should be affected in the same way; different readers read differently, and the material is rich enough to transform readers in different ways. But I trust that readers will recognize at least some affinities to their own reading experience, particularly if they have been reading these same texts.

More to the point, however, is to ask something of the readers of this essay: have other readers, Hindus who read certain Christian texts, and Christians who read certain Hindu texts, identified ways in which their reading and writing, and attitudes toward Hindu-Christian studies, have been shaped by their particular work? If it turns out that scholars contribute differently to Christian-Hindu studies because of what they have been reading, then, as suggested at the beginning of this essay, the tracing of these differences will be an interesting and important part of the progress of Hindu-Christian studies. It is intrinsic to our cooperative enterprise, well assisted by this new journal, to share this raised self-consciousness of ourselves as readers and writers of a particular kind, and so to ascertain more clearly our goals and audiences in reading and writing as we do. 